УДК 821.161.2-3.09:39(477)

Троша Наталія, кандидат філологічних наук, старший викладач кафедри української мови, літератури та методики навчання Глухівський національний університет імені Олександра Довженка

\title{
НАЦІОНАЛЬНО-ПАТРІОТИЧНІ СМИСЛИ ТА СЕНСИ ЕТНОКУЛЬТУРНОГО ПОТЕНЦІАЛУ TВОРІВ О. ДОВЖЕНКА
}

\begin{abstract}
У статті розглянуто концептуальні домінанти як елементи аторсъкого стилю О. Довженка. Проаналізовано художні форми реалізації етнокультурних концептів як ваэливого чинника формування національної свідомості й патріотизму украӥниів. Доведено, що ключовими етнокониептами багатъох його творів (оповідань, кіноповістей, драматичних творів) та щоденникових записів стали концепти «історія», «козак», «запорожецъ», «могила», «Украӥна» та ін. Резюмовано, що за допомогою концептів націоналъного в творчості писъменника репрезентуетъся ментальність українсъкого народу, його самобутність та иінністъ.

Ключові слова: кончепт, етноконцепт, концептосфера, історія, Украӥна, козак, могила, начіональна свідомість, патріотизм.
\end{abstract}

Trosha N. National-patrotic means and sense of the ethnocultural potential of the works of O. Dovzhenko.

O. Dovzhenko's creativity contain many ethno-national thoughts, ideas, images, metaphors, symbols and concepts that have not lost their relevance today. Among them is the Ukrainian national idea, the issue of nationalcultural traditions' continuity, the need for a spiritual foundation for state creation, a balanced ethno-national and humanitarian policy of Ukraine, etc. In fact, from O. Dovzhenko begins the conscious creation of the Ukrainian nation principles as a unique phenomenon and fact of world history. Therefore, the works of O. Dovzhenko need to be read in accordance with the purpose of Ukrainian literature's studying in school, namely: senior pupils' humanistic world outlook formation, their involvement by means of art literature to universal and national values, the education of nationally conscious citizens of Ukraine, etc.

The article deals with the conceptual dominants as an element of the author's style of $O$. Dovzhenko. The author of the article analyzes the artistic forms of ethno-cultural concepts' realization as an important element of master's literary works ideologically themed spectrum formation. It is proved that the core ethno-concepts of lot of his works (stories, film stories, dramatic works) and diary entries has become such concepts as «history», «cossack», «zaporozhets», «grave», «Ukraine», etc. It is summarized that the Ukrainian 
people mentality, its identity and value are represented in the works of the writer with the help of the national concepts.

Key words: concepts, ethno-concepts, concept sphere, history, Ukraine, cossack, grave, national consciousness, patriotism.

Постановка проблеми у загальному вигляді та їі зв'язок з важливими науковими чи практичними завданнями. У творчості О. Довженка міститься багато етнонаціональних думок, ідей, образів, метафор, символів і концептів, що не втратили своєї актуальності й сьогодні. Серед них - українська національна ідея, питання безперервності національно-культурних традицій, необхідності духовного підгрунтя для державотворення, збалансованої етнонаціональної та гуманітарної політики України тощо. Власне, з О. Довженка починається цілком свідоме творення засад української нації як окремого неповторного явища і факту всесвітньої історії. Відтак твори О. Довженка потребують нового прочитання відповідно до мети шкільного вивчення української літератури, а саме: формування гуманістичного світогляду старшокласників, долучення їх засобами художньої літератури до загальнолюдських і національних цінностей, виховання національно свідомих громадян України тощо.

Концептосферу українського народу формують такі поняття, як Бог, Україна, Дніпро, село, сад, хата, козак, запорожець, чумак, могила та ін., які є суб'єктами маніфестації універсалій в етносоціокультурних хронотопах. Олександр Довженко в своїй літературній спадщині особливо багато уваги приділяв етнокультурним концептам, які стали стильовою домінантою його творчого доробку. Ключовим етноконцептами багатьох його творів (оповідань, кіноповістей, драматичних творів) та щоденникових записів стали концепти «Україна», «історія», «козак», «запорожець», «могила» та ін.

Аналіз останніх досліджень і публікацій з даної теми, виділення невирішених раніше частин загальної проблеми, котрим присвячується означена стаття. Творчість Олександра Довженка - визнаного в світі майстра кіно і літератури - вивчається вже майже дев'яносто років. В останні десятиліття з'явилися роботи узагальнюючого, оглядового критико-біографічного характеру. Зокрема, це стосується наукових праць Р. Корогодського, М. Куценка, В. Марочка, С. Мащенка, С. Тримбача, у яких досить грунтовно і різнобічно вивчене життя і творчість О. Довженка. Дослідження цих авторів були опубліковані здебільшого після розсекречення архівних матеріалів, починаючи з 2000 року. 
Сучасні довженкознавці А. Новиков, С. Максимчук-Макаренко, С. Привалова, Н. Троша, С. Цінько у своїх наукових розвідках звертаються до етнокультурних концептів як стильової домінанти творчості митця.

Мета статті - дослідити художні форми реалізації етнокультурних концептів літературної творчості (оповідань, кіноповістей, сценаріїв, щоденникових записів) Олександра Довженка як важливого чинника формування національної свідомості й патріотизму українців; запропонувати сучасні підходи до нового прочитання художньої спадщини митця.

Виклад основного матеріалу дослідження 3 повним обгрунтуванням отриманих наукових результатів. На сучасному етапі розвитку літературознавства актуальним є опис авторських концептів як елементів індивідуального стилю письменника, оскільки метод концептуального аналізу передбачає глибинне проникнення у зміст художнього твору. Ідеєю концептуального аналізу літературного твору охоплено цілий ряд вагомих праць і наукових полемік 3 окресленої проблеми. Провідними учасниками наукових дискусій i авторами досліджень у цій галузі є Н. Арутюнова, А. Вержбицька, С. Воркачов, С. Жаботинська, В. Карасик, О. Селіванова, Ю. Степанов, Й. Стернін, М. Піменова, З. Попова та ін.

Термін «концепт» активно використовується в різних галузях науки: літературознавстві, психолінгвістиці, філософії, історії, філософії мови, когнітології, етнолінгвістиці, соціолінгвістиці. У цілому всі сучасні підходи до розуміння концепту зводяться до лінгвокогнітивного та лінгвокультурного осмислення цього явища. Вітчизняні й закордонні вчені займаються дослідженням таких концептів: страх (Ю. Апресян, Р. Валієва), щастя (С. Воркачов), людина (Л.Бояркіна), воля (О.Яцкевич), час (О. Задорожна), правда / неправда (Ж. Апєкова), гнів, злість (Дж. Лакофф), чоловік (А. Гайфулліна), сором (Н. Арутюнова), жінка (С. МаксимчукМакаренко), Україна (А. Новиков), історія (Н. Троша) та ін.

Етнокультурні концепти, зокрема «козак», «запорожець», були знайомими і близькими для О. Довженка з дитинства. Оскільки родом він був із козацького краю - Сіверщини. За переказами, пращури Довженків були козаками, які десь у середині XVIII століття прибули до Сосниці з Полтавщини. Сам митець в «Автобіографії» так визначав своє походження: «Народився я 30 серпня 1894 року на околиці невеликого повітового містечка Сосничі на Чернігівщині, що звалося В'юнище, у родині хлібороба Петра Семеновича Довженка, який належав до козацького, як на ті часи, стану» $[1$, с. 18]. 
Згодом концепт «запорожець» пройде наскрізною ниткою через усю творчість митця. Часто письменник наділяє своїх героїв рисами, притаманними козакам, дає прізвища козацького походження: Кошовий, Скидан, Чорнота, Заброда, Паливода, Запорожець. Останнє акумулює випробувані часом кращі риси українців: козацьку відвагу, вірність своїй Батьківщині, глибоке усвідомлення відповідальності за долю рідних людей, що є в Довженковому розумінні запорукою безсмертя нації. Таке світобачення відіграло помітну роль у подальшій долі митця. Через багато років по тому він буде проходити в матеріалах спецслужб саме під прізвиськом «Запорожець».

О. Довженко, який зростав у козацькій родині, на землі 3 міцними козацькими традиціями, а потім навчався у місті зі славетним козацьким минулим, часто порушував у своїй літературній, кінематографічній та публіцистичній творчості тему українського козацтва. Письменник неодноразово у роздумах звертається до концепту «козак» і на сторінках «Щоденника».

У щоденникових записах письменника концепт «козацтво» виражається такими концептуальними сферами: історична географія, етнографічна сфера i суспільно-політичні субконцепти. До концептуальної сфери історичної географії можна віднести природноспецифічні субконцепти (байрак, балка, урочище, Дніпрові пороги тощо), які трапляються у «Щоденнику». 3 етнографічної сфери митець використовує назви речей побуту (житло, їжа, одяг), господарських занять козацтва (види діяльності, люди, організація праці, знаряддя), козацької культури (клейноди, звичаї, вірування, розваги). Суспільнополітичні субконцепти, вживані Довженком, - це назви органів та носіїв влади, військових чинів і підрозділів, родів військ. Наприклад, Гетьманщина, Рада козацька, козацька старшина, сотник, сотня, кошовий тощо.

Розробляючи концепт «козацтво» у своїх літературних творах, О.Довженко використовує специфічні історичні номінації, що означають предмети матеріальної і духовної культури та характеризуються певною національною забарвленістю. Це назви географічних об'єктів і персоналій, особливості військової бази, економічних відносин і суспільно-політичної організації, що пов'язані з історією козацтва.

Письменник не повністю погоджувався з міфологізованим образом запорізького козацтва, хоч його твори містять багатий народознавчий матеріал: перекази про Запорозьку Січ та легендарних козаків, козацькі традиції та обряди, легенди, козацькі пісні тощо. Час від 
часу у творах зринають образи захисників рідної землі - запорожців, через які автор метафорично намагається акцентувати на героїчній боротьбі козаків із ворогами й поневолювачами. Через картини старовини проступають небезпечні для того часу історичні погляди митця. Композиційним принципом літературних творів О. Довженка є протиставлення минулого, що асоціювалося з волею, сучасному, яке пов'язувалося з неволею і деградацією. Ідея мужності й хоробрості вивищувалася над буденним сучасним.

Таким чином, концепт «козацтво» за індивідуально-авторським осмисленням письменника - це символ відваги, самопожертви, мужності, національної ідентичності. Він відображає досвід попередніх поколінь і накладає відбиток на менталітет української нації.

Оперуючи іменами історичних постатей, досліджуючи історичні процеси та явища, письменник спирався на факти, розуміючи, що історія - це упорядкована система, яка має свою часову послідовність і просторову структуру. Крім того, у його творах постійно відчувається, що історія завжди представлена часовими рамками «минуле теперішнє». Причому минуле впливає на теперішнє, оскільки у свідомості людей існують архетипи, у які закладено основи буття. Митець намагається переконати читача в циклічності історії. Він доводить, що ніщо не трапляється випадково, а $є$ результатом попередньої дії або бездіяльності, знання історії - необхідна умова прогресу, змін на краще. Усупереч офіційній комуністичній ідеології однією 3 провідних у його літературному доробку $є$ думка про важливість вивчення співвітчизниками історії свого народу невичерпного джерела виховання національної самосвідомості й патріотизму.

Аналіз літературної спадщини Олександра Довженка підтверджує вагомість історичного матеріалу в житті й творчості митця. Концепт історії в письменника пов'язаний передусім із визначенням i вираженням його ставлення до історичного минулого, зокрема, до часів Київської Русі, доби козаччини, громадянської і Другої світової воєн. Саме крізь призму зазначених історичних подій він розглядав те, що відбувалося в сучасній йому Україні. Художні твори майстра охопили найважливіші віхи історії нашого народу (XVII ст. - «Тарас Бульба»; XX ст. - «Арсенал», «Земля», «Щорс», «Мати», «Стій, смерть, зупинись», «Воля до життя», «Перемога», «На колючому дроті», «Україна в огні», «Повість полум'яних літ», «Потомки запорожців», «Зачарована Десна» тощо). 
У літературній творчості О. Довженка концепт історії є наскрізним, що пов'язано з особливою увагою митця до минулого українського народу, з притаманним йому розумінням проблем історії. Творча спадщина письменника є специфічним історичним джерелом, що може використовуватися не тільки літературознавцями, а й істориками для аналізу відповідного історичного періоду, ілюстрації певних положень, для посилення емоційного сприйняття історичного матеріалу, а також у процесі вивчення епохи створення самого художнього твору, ідеології його автора, впливу на нього реалій сучасного йому життя.

Історія, на думку О. Довженка, $є$ небезпечною для щастя й добробуту того, хто намагається її дослідити. Неприйняття суб'єктивної історії, яка нав'язувалася владою, пошук істини, прагнення до пізнання суті подій та явищ несуть загрозу пошукачеві. Відбувається зіставлення концептів «історія» і «правда», які протиставляються як «суб'єктивне об'єктивне». Це пов'язано з тим, що історія знаходиться в часових рамках, а правда існує незалежно від часу й простору.

Дослідження концепту історії в літературній творчості О. Довженка дозволяє глибше зрозуміти його ідейний задум, особливості долучення письменника до традиції. Творчий доробок митця містить великий обсяг історичного матеріалу, що охоплює сюжети, постаті, епохи, явища в загальному культурно-історичному контексті. Часто ця інформація подається не відкрито, а завуальовано, шляхом авторського затемнення або в підтексті.

Загальна концепція історії в О. Довженка складається насамперед з його висловлювань про неї, а також із висловлювань героїв творів, які є виразниками його поглядів на історичні події та постаті. Основна роль відводиться індивідуальності образу автора, що інколи знаходить відображення не в самому тексті, а у вигляді асоціацій. Отже, концепт дозволяє розглянути в єдності текстовий та позатекстовий простори.

Концепт історії у творчості О.Довженка реалізується через відображення знань і уявлень автора про відповідну епоху, історичні події, культуру, духовне життя, рівень історичної свідомості суспільства, що домінують в окремому художньому творі чи в усьому літературному доробку, $є$ його ідейним задумом. Тобто зазначений концепт є одиницею свідомості письменника, що отримує свою репрезентацію в художньому творі чи сукупності творів і виражає індивідуально-авторське осмислення сутності предметів і явищ. Концепт історії в довженківських творах характеризується образністю й символічністю. Він підпорядковується особливій прагматиці «художній асоціативності», розкривається як символ, знак, потенційно й динамічно направлений на сферу заміщення. 
Літературний доробок О. Довженка є виявом роздумів автора над проблемою історії, що характеризуються своєрідним її баченням, яке суттєво відрізнялося від офіційної радянської ідеології. Свідченням альтернативності довженківського розуміння історії є інтертекстуальна орієнтація на народнопоетичну творчість, давньоруські тексти («Слово о полку Ігоревім», «Повість минулих літ»). Реверсивність історії митець доводить орієнтацією персонажів на більш давні історичні часи, відтворені в міфах, переказах, легендах, народних піснях. Виявом інтертекстуальності його творів $є$ алюзії, натяки, апеляції до історичних подій та постатей.

Семантичний пласт літературних творів О. Довженка, що містять інтертекстуальні конструкції, складають міфофольклорні образи, у тому числі й давньогрецької міфології, елементи міфопоетики, міфологеми землі, роду, хати, могили, мотиви творчості М. Гоголя й Т.Шевченка, засоби літописного письма, архетипи української ментальності. Авторська стилістика характеризується зв'язком із фольклорними традиціями і кіномистецтвом, взаємодією історичного, фольклорного й міфологічного кодів. Особливості авторської концепції реалізуються через апелювання до язичницьких символів і образів. Національний характер відтворено через архетипи мудрих дідів, матері - берегині роду, хоробрих і відважних козаків.

Концепт історії в літературній творчості О. Довженка тісно взаємодіє з іншими домінантними елементами його концептосфери «історична пам'ять», «історична правда», «козацтво», «запорожець». Своєю чергою, зона досліджуваного концепту «історична пам'ять» у доробку майстра експлікується лексемами «історія», «нащадки», «безсмертя», наповненими новим змістом, авторським задумом.

У своїй літературній творчості О. Довженко постійно звертається до етноконцепт «могила». Митець упевнений, що за законами природи все з'являється з-під землі, живе і врешті-решт іде в ту ж землю, в могилу. Разом із тим люди не зникають безслідно, вони обов'язково залишають по собі слід, спадок, пам'ять. Ми постійно відчуваємо наших пращурів, вони живуть у нас, звертаються до нащадків своїх, застерігають їх від помилок. Особливо відчутний цей зв'язок на могилах.

Заглядаючи в «могили», тобто у своє минуле, свою історію, ми можемо зрозуміти, хто ми. Рядки довженківських творів рясніють цим символом, вони сповнені картин спілкування живих із мертвими. Так, персонаж кіноповісті «Земля» Григорій ходив на могилу до свого товариша, щоб згадати минуле, подумати про сучасне, i врешті-решт «удостоївся тиші поряд свого побратима» [1, с. 135]. В 
оповіданні «Тризна» митець заводить розмову про те, що перебування на могилках - це особливий момент: на могилках найсильніше відчувається безсмертя народу, тому селяни збираються на кладовищі, поминають загиблих. Автор констатує: «Життя тоді тихо пануе над небуттям» $[1$, с. 319]. Олеся 3 оповідання «Незабутнє» не пішла за коханим Василем у далекі краї, бо відчувала нерозривний зв'язок із землею, хатою і «дорогими могилами батъків» [1, с. 105]. Звертаючись до етнокультурного концепту «могила», автор намагався продемонструвати взаємозв'язок часів, різних епох.

Концепт «Україна» репрезентовано письменником передусім через трагічні жіночі образи, які уособлюють страждання і біль, горе і розпач українського народу. Найяскравіше цей концепт розкрито у кіноповісті «Україна в огні», яка у творчій біографії О. Довженка посідає осібне місце і є одним із найкращих його творів.

26 листопада 1943 року у своєму «Щоденнику» митець зробив такий запис: «Мені важко од свідомості, що "Украӥна в огні" - це правда. Прикрита і замкнена моя правда про народ $і$ його лихо» [2, с. 412]. Через те, що весь твір із першого до останнього рядка пронизаний правдою, його замовчували так довго. Тільки 1966 року уперше кіноповість було надруковано, але й після такої довгої мовчанки у ній було багато цензурних купюр.

«Україна в огні» - твір про трагедію українського народу. Сьогодні цілком аргументовано українські й закордонні дослідники стверджують, що сталінський режим був тоталітарним, антинародним. Злочинне нехтування долями тисяч людей призвело до численних трагедій, непоправних втрат, катастроф, смертей. Кіноповість «Україна в огні» була одним із перших творів, у якому на тлі смертельного двобою $з$ фашизмом принципово ставились проблеми гуманізації суспільства й особистості, заперечення війни.

Використання О.Довженком різноманітних інтертекстуальних конструкцій актуалізує сюжети й деталі з творів класиків світової літератури, проектує їх на зображувану дійсність. Тим самим дає можливість автору завуальовано висловлювати власні судження 3 приводу сучасних йому подій і явищ. Митець прагне дати у своєму творі не історичну довідку про певні події, а звертається до історії, прагнучи знайти причини трагедії свого народу. Автор чітко окреслює проблему збереження історичної пам'яті, що у його розумінні $\epsilon$ запорукою безсмертя нації.

Висновки 3 дослідження i перспективи подальших пошуків у даному науковому напрямку. Концептосфера 
літературної творчості О. Довженка є надзвичайно різноманітною та полісемантичною. Вона дозволяє нам простежити цілісність національного світогляду, що існує у глибинній національно-культурній традиції і всеохопності національного світоглядного мислення, зокрема природно-астрального, господарського та родинного.

Підсумовуючи, варто зауважити, що за допомогою концептів національного в творчості О. Довженка репрезентується ментальність українського народу, його самобутність та цінність. Творча спадщина митця - невичерпне джерело виховання в учнівської молоді національної свідомості і патріотизму. Перспективи подальших досліджень вбачаємо у детальному аналізі особливостей інтерпретації етноконцептів у творчості О.Довженка та інших українських письменників, можливості їх використання на уроках української літератури і позакласній роботі з метою формування національної свідомості й патріотизму учнів.

\section{Література}

1. Довженко О. П. Твори : В 5-ти т. Київ : Дніпро, 1983. Т. 1. 439 с.

2. Довженко О.П. Щоденникові записи, 1939-1956. Харків: Фоліо, 2013. $879 \mathrm{c}$. 